\title{
Comparative study between intramedullary interlocking nailing and minimally invasive percutaneous plate osteosynthesis for distal tibia extra-articular fractures
}

\author{
Anil Kumar ${ }^{1}$, Johney Juneja ${ }^{1 *}$, Raghvendra Choubisa ${ }^{1}$, \\ Nitin Jeenjwadia ${ }^{1}$, A. K. Mehra ${ }^{1}$, Ramesh Sen ${ }^{2}$
}

${ }^{1}$ Department of Orthopaedics, RNT, Udaipur, Rajasthan, India

${ }^{2}$ Orthopaedic Department, Max Hopsital, Mohali, Punjab, India

Received: 04 September 2021

Revised: 12 October 2021

Accepted: 13 October 2021

\section{*Correspondence:}

Dr. Johney Juneja,

E-mail: johney.johney2008@gmail.com

Copyright: (c) the author(s), publisher and licensee Medip Academy. This is an open-access article distributed under the terms of the Creative Commons Attribution Non-Commercial License, which permits unrestricted non-commercial use, distribution, and reproduction in any medium, provided the original work is properly cited.

\begin{abstract}
Background: Treatment of distal tibia fractures poses significant challenge to orthopedic surgeon because of poor blood supply and paucity of soft tissue coverage. There is considerable controversy regarding the superior option of treatment for distal tibia fracture between the minimally invasive percutaneous plate osteosynthesis (MIPPO) technique and intramedullary interlocking (IMIL) nailing for extra-articular distal tibia fractures. The aim of our study is to compare the functional outcome between the two treatment methods.

Methods: This was the prospective comparative study of 50 patients with distal third tibia fractures divided into two groups. First group of patients were treated with MIPPO technique while second group of patients were managed by IMIL nailing. Patients were followed up in outpatient department to assess the functional outcomes, malunion, delayed union, non-union, superficial and deep infection between the two groups.

Results: Average time taken by patients for full weight bearing in group A was 17.6 weeks as compared to 16.7 weeks in group B. All patients were able to bear weight prior to complete union of fracture. By the process of weight bearing, we believed that it would promote secondary bone healing. On taking X-rays during follow up of included patients starting of radiological union was observed carefully by looking for bridging callus, haziness of fracture line. Appearance of callus was taken average time of 12.5 weeks in group A and 12.1 weeks in group B.

Conclusions: Both procedures have shown the reliable method of fixation for distal extra-articular tibia fractures preserving the soft tissue, bony vascularity and fracture hematoma that provide a favourable biological environment for fracture healing. Considering the results of the study, we have slightly more preference for the MIPPO technique.
\end{abstract}

Keywords: Tibial fractures, Malunion, Bone plates, Intramedullary interlocking nailing

\section{INTRODUCTION}

As the civilization proceeds towards industrialization more and more accidents have been experienced. In almost all the leg bone fractures over the world, the incidence of road traffic and industrial accidents are growing up, resulting in fracture of various bones of body. If we scrutinize the statistics of fractures in body parts, leg bones fracture comes at the top because it is the most distal part of the body and actively involves in locomotive system. ${ }^{1}$

Out of all the leg bones fracture, on basis of fracture location in tibia distal tibia fracture have second highest incidence. ${ }^{2}$ As these fractures occur in proximity of weight 
bearing surface of ankle joint, a slight maladjustment in inclination of ankle joint may lead to permanent disability.

Distal tibia fractures are complex injuries with high complication rate. Traditionally, a variety of methods of management have been described with a reportedly high rate of associated complications. Non-operative treatment of these fractures can be unsatisfactory with poor hold in plaster. There may be associated joint stiffness, shortening and rotational mal-union.

In addition, there is sizeable incidence of non-union which is difficult to manage at a later stage on account of disuse osteoporosis.

Many osteosynthesis techniques can be used for this fracture such open reduction and internal fixation with locking plate, External fixation with or without limited internal fixation, Intra-medullary nailing. All of these techniques have their pros and cons, also, there is no consensus concerning the management of these fractures.

External fixation (Iliazarov frames, ankle spanning and hybrid constructs) have been proposed either as a sole treatment or, more frequently in conjunction with limited internal fixation has an established place in treatment of distal tibial fractures, particularly when associated with significant soft tissue injury. Complications of external fixation, include the development of pin tract infection, malunion or nonunion.

Intramedullary nails have been greatly improved in recent years and indication for their use have been extended to fractures closer to the ankle joint.

Modern tibial nail designs have interlocking holes that enable distal placement of screws in close proximity to tip of nail. Also success of at least two interlocking screw in the distal fragment after removal of the distal tip of the traditional nail has been reported. ${ }^{24}$ Theclosed intramedullary nailing also has been associated with significantly shorter operative time and fewer wound infection (AO/ASIF).

The surgical treatment of fractures has evolved a great deal since the development of the original "open reduction and internal fixation" technique by the AO group. To obtain maximal mechanical stability in order to achieve primary (endosteal) bone healing, exact anatomical reduction and strict rigid fixation were emphasized in the beginning. This however can rarely be obtained without significant dissection of the fracture and the surrounding soft tissues. Well-known complications like infection and delayed or non-union are frequently attributed to the devitalisation of bony fragments and additional damage to the soft tissues.

In order to improve fracture healing, more "biological" methods have been developed over the last decades, trying to lessen the surgical dissection, preserving the blood supply to the bony fragments and containing at least partially the fracture hematoma.

More and more new insights in reduction techniques and fracture healing are leading to the development of a "minimally invasive osteosynthesis" promoted by the AO group and others. The emphasis now lies percutaneous plate on indirect reduction (MIPPO)18, axial alignment and stable fixation without disturbing the fracture environment and thus preserving most of the vascularization and fracture hematoma, containing all necessary growth factors for bony healing. ${ }^{6,7}$ There has been an increasing trend towards the use of the locking compression plate (LCP) for fracture fixation. The device allows the screws to lock to the plate, therefore creating a stable, fixed angle device. Precise anatomical contour of this plate is no longer necessary because the plate does not need to be pressed on the bone to achieve stability, thus preventing the loss of primary reduction of fracture fragments caused by inadequate contouring of the plate.

Limited literature exists, comparing method of treatment distal tibial fractures. Plates and intramedullary nails are well accepted and effective methods but has historically related to some complications and knee pain are frequently associated with intramedullary nailing whereas infections, wound complications and implant prominence has been associated with plating in some series. The purpose of this study was to compare plate and nail stabilization for distal tibial fracture by assessing the treatment results and complications.

\section{Aims and objectives}

To study the management of distal metaphyseal fracture of tibia (extra articular) using interlocking intra-medullary nailing and locking plate fixation. To assess and compare the end result of above procedure in terms of benefits and complications.

\section{METHODS}

This study was carried out prospectively on the patients having fracture of distal third of tibia, admitted in the Department of Orthopedics, R.N.T. Medical College and Maharana Bhupal Government Hospital, Udaipur during August 2019 to November 2020, treated with surgical methods either by close interlocking intramedullary nailing or with open/percutaneous reduction and internal fixation with LCP plating. In the study percutaneous reduction and plating through minimal invasive technique was preferred and open reduction was done in those cases where acceptable reduction was not achieved with minimal invasive technique. All cases were followed up for a minimum period of six months.

\section{Inclusion criteria}

All closed extra articular distal Tibia fractures as per AOClassification 43A1, 43A2, 43A3 with Tsherene and 
Group A is designated for patients those are operated with distal tibia pre-contoured LCP.

Group B is designated for patients those are operated with interlocking intramedullary nailing.

Following are the observation of the studies:

Ostern grade 0 and grade 1 . Age more than 18 years. Open fracture grade 1 (Gustillo and Anderson classification).

\section{Exclusion criteria}

Age below 18 years. Intra-articular extension of fractures. Open Fractures above grade 1 according to Gustillo and Anderson. All Pathological fractures. Earlier fracture of tibia on same side. Temporary treatment of fracture with external fixator. Unfit for surgery. Lost follow up.

\section{The management of injury was based on the following protocol}

Laboratory investigations included CBC ESR, BT, CT, PT-INR, urea, creatinine, random blood sugar, fasting and post prandial sugar if needed, blood grouping, HIV, HBsAg and HCV.

\section{Technique for closed interlocking intramedullary tibia nailing}

After application of tourniquet under the same condition above, a vertical incision around $5 \mathrm{~cm}$ was made on the anterior aspect of knee from distal tip of patella to proximal aspect of tibial tuberosity. After splitting the patella tendon, entry portal was made in the bare area of tibia extra-articularly around $2 \mathrm{~cm}$ proximal to tibial tuberosity. Central position of entry point was confirmed in $\mathrm{C}$-arm with AP and lateral views. A ball tip guide wire was passed through the entry portal and extended up to the distal end of tibia after provisional reduction of fracture. Intramedullary confirmation of guide wire was confirmed in the C-arm again on both AP and lateral views. After perfect reduction of fracture, that sometimes requires use of pointed bone holding forceps, sequential reaming was done and fixed with suitable length IMIL nail. The nail was fixed with two distal locking screws and one or two proximal locking screws. Sometimes fracture stability and alignment was enhanced with anteroposterior interlocking screw and/or polar blocking screw.

\section{Postoperative protocol}

Postoperatively the fracture was supported with posterior slab for 2 weeks. Standard AP and lateral views of leg were taken immediately after surgery (Figure 2B). Active quadriceps and calf strengthening exercises were started next day after surgery. Postoperative intravenous antibiotic was given for three days. Wound was inspected on third postoperative day for any sign of wound infection and soakage. Patients were discharged within one week if skin condition was satisfactory and wound was dry.

\section{Technique for plating for distal tibia}

\section{MIPPO technique}

The leg was prepared circumferentially from toes to midthigh after application of tourniquet. Approximately 3 to 4 $\mathrm{cm}$ longitudinal incision was made over the distal tibia metaphysis preventing the injury of saphenous nerve and vein. Now epiperiosteal tunnel was made either by a blunt retractor or by blunt tip of long plate inserting through the incision towards diaphysis. After traction, manipulation and reduction of fracture, anatomical precontoured plate was positioned on anteromedial aspect of tibia shaft depending on the pattern of fracture. Varus-valgus angulation $<5^{\circ}$ and anteroposterior angulation $<10^{\circ}$ and shortening of $<15 \mathrm{~mm}$ was considered acceptable criteria for reduction. After insertion of plate and achieving the reduction, the plate was temporarily fixed to bone with $\mathrm{K}$ wires and fixed proximal fragment with one locking screw. Distal fragment fixation was completed with combination of cortical nonlocking and locking screws with or without lag screw. Lag screw, if required was inserted either separately or through the nonlocking hole of plate. Fibula was not routinely fixed unless fracture was within syndesmosis region or within 7 to $10 \mathrm{~cm}$ from tibia plafond.

Locking plate was applied to surface with the plate in-situ and traction given manually and fracture was reduced the alignment was checked using the standard anterior superior iliac spine-centre of patella-second toe guide line.

An IITV was taken to check correct restoration of axial alignment.

\section{Follow-up}

Suture and posterior slab were removed 2 weeks after surgery. Active range of movements of the knee and ankle joint along with quadriceps strengthening exercises were started. Patients were followed up in outpatient department every six weeks for six months and then every three months thereafter. Post-operative radiograph was performed during each visit in outpatient department. Partial weight bearing was started once callus was visible in radiograph possibly from 6 to 8 weeks. Fracture union was considered when definitive callus was visible in three out of four quadrants on both AP and lateral views along with clinical evidence of no pain and mobility on fracture site. If union was not progressed satisfactorily, treatment in the form of bone marrow injection or bone grafting was considered. A clinical evaluation for the functional assessment of the ankle was obtained at one year after surgery or once complete union of fracture has occurred. 


\section{RESULTS}

The present study was aimed at assessing the outcomes of fracture of distal tibia stabalized either intramedullary nailing or with distal tibia pre-contoured LCP.

The study was performed on a total of 50 patients. Of these, 25 patients were allotted in each group i.e. Group A and Group B in department of orthopaedic, RNT Medical college, Udaipur, between August 2019 to November 2020 .

Group A is designated for patients those are operated with distal tibia pre-contoured LCP.

Group B is designated for patients those are operated with interlocking intramedullary nailing.

Following are the observation of the studies:

Table 1: Time taken to full weight bearing.

\begin{tabular}{|lllll|}
\hline $\begin{array}{l}\text { Time to } \\
\text { full wt } \\
\text { bearing }\end{array}$ & $\begin{array}{l}\text { Group A } \\
\text { No. of } \\
\text { Patients }\end{array}$ & $\%$ & $\begin{array}{l}\text { No. of } \\
\text { Patients }\end{array}$ & $\%$ \\
\hline $\begin{array}{l}\mathbf{1 0 - 1 5} \\
\text { weeks }\end{array}$ & 5 & 20 & 8 & 32 \\
\hline $\begin{array}{l}\mathbf{1 6 - 2 0} \\
\text { weeks }\end{array}$ & 16 & 64 & 16 & 64 \\
\hline $\begin{array}{l}\mathbf{2 1 - 2 5} \\
\text { weeks }\end{array}$ & 4 & 16 & 1 & 4 \\
\hline Total & 25 & & 25 & \\
\hline $\begin{array}{l}\text { Average } \\
\text { mean time }\end{array}$ & & 17.6 & & $\begin{array}{l}\text { Group B } \\
\text { weeks }\end{array}$ \\
\hline
\end{tabular}

Table 2: Time taken for appearance of callus on $\mathrm{x}$ rays.

\begin{tabular}{|lllll|}
\hline Time & $\begin{array}{l}\text { Group A } \\
\text { No. of } \\
\text { Patients }\end{array}$ & $\%$ & $\begin{array}{l}\text { Group B } \\
\text { No. of } \\
\text { Patients }\end{array}$ & $\%$ \\
\hline $\begin{array}{l}\text { Less } \\
\text { than 10 } \\
\text { weeks }\end{array}$ & 6 & 24 & 8 & 36 \\
\hline $\begin{array}{l}\mathbf{1 1 - 1 5} \\
\text { weeks }\end{array}$ & 16 & 64 & 14 & 56 \\
\hline $\begin{array}{l}\mathbf{1 6 - 2 0} \\
\text { weeks }\end{array}$ & 3 & 12 & 2 & 8 \\
\hline Total & 25 & 12.5 & & 12.1 \\
\hline $\begin{array}{l}\text { Average } \\
\text { mean } \\
\text { time }\end{array}$ & & weeks & & weeks \\
\hline P= & & & & \\
\hline
\end{tabular}

Average time taken by patients for full weight bearing in group A was 17.6 weeks as compared to 16.7 weeks in group B. All patients were able to bear weight prior to complete union of fracture. By the process of weight bearing we believed that it would promote secondary bone healing.

Table 3: Time taken to fracture union.

\begin{tabular}{|lllll|}
\hline $\begin{array}{l}\text { Time to } \\
\text { fracture } \\
\text { union }\end{array}$ & $\begin{array}{l}\text { Group A } \\
\text { No. of } \\
\text { Patients }\end{array}$ & $\%$ & $\begin{array}{l}\text { Group B } \\
\text { No. of } \\
\text { Patients }\end{array}$ & $\%$ \\
\hline $\begin{array}{l}\text { Less than } \\
\text { 20 weeks }\end{array}$ & 2 & 8 & 4 & 16 \\
\hline $\begin{array}{l}\mathbf{2 1 - 2 5} \\
\text { weeks }\end{array}$ & 5 & 20 & 5 & 20 \\
\hline $\begin{array}{l}\mathbf{2 6 - 3 0} \\
\text { weeks }\end{array}$ & 18 & 72 & 16 & 64 \\
\hline Total & 25 & 25 & & 25.6 \\
\hline $\begin{array}{l}\text { Average } \\
\text { mean } \\
\text { time }\end{array}$ & & 27.1 & & weeks \\
\hline
\end{tabular}

$\mathrm{P}$ value $=0.141(\mathrm{NS})$

Table 4: Technique used in plating group.

\begin{tabular}{|lll|}
\hline Technique & $\begin{array}{l}\text { No. of } \\
\text { patients }\end{array}$ & $\%$ \\
\hline Conventional & 6 & 24 \\
\hline MIPO & 19 & 76 \\
\hline Total & 25 & \\
\hline
\end{tabular}

Table 5: Maximum angulation in any plane at final follow up.

\begin{tabular}{|lllll|}
\hline $\begin{array}{l}\text { Angulation } \\
\text { in any plane } \\
\text { (in degrees) }\end{array}$ & $\begin{array}{l}\text { Group A } \\
\text { No. of } \\
\text { Patients }\end{array}$ & $\%$ & $\begin{array}{l}\text { Group B } \\
\text { Po. of } \\
\text { Patients }\end{array}$ & $\%$ \\
\hline Less than $\mathbf{5}^{\mathbf{0}}$ & 24 & 96 & 21 & 84 \\
\hline $\mathbf{5 - ~ 1 0}^{\mathbf{0}}$ & 1 & 4 & 4 & 16 \\
\hline $\begin{array}{l}\text { More than } \\
\mathbf{1 0}^{\mathbf{0}}\end{array}$ & 0 & - & 0 & - \\
\hline Total & 25 & & 25 & \\
\hline
\end{tabular}

$\mathrm{P}$ value $=0.317(\mathrm{NS})$

On taking X-rays during follow up of included patients starting of radiological union was observed carefully by looking for bridging callus, haziness of fracture line. Appearance of callus was taken average time of 12.5 weeks in group A and 12.1 weeks in group B.

Average time taken for union of fracture in our study groups was 27.1 weeks in group A and 25.6 weeks in group B. Union was defined clinically as the ability to walk without aid or pain and radiologically as a solid callus bridging of the fragments. 
Most of patients in group B were operated with MIPO technique. Conventional open reduction was used in $24 \%$ of cases only.

Table 6: Shortening in patients at final follow up.

\begin{tabular}{|lll|ll|}
\hline $\begin{array}{l}\text { Shortening } \\
\text { at final } \\
\text { follow up }\end{array}$ & $\begin{array}{l}\text { Group A } \\
\begin{array}{l}\text { No. of } \\
\text { Patients }\end{array}\end{array}$ & $\%$ & $\begin{array}{l}\text { Group B } \\
\text { No. of } \\
\text { Patients }\end{array}$ & $\%$ \\
\hline $\begin{array}{l}\text { Less than } \\
\text { 5 mm }\end{array}$ & 23 & 92 & 21 & 84 \\
\hline 6-10 mm & 2 & 8 & 4 & 16 \\
\hline Total & 25 & & 25 & \\
\hline
\end{tabular}

Table 7: Comparison of olerud molander score at final follow up.

\begin{tabular}{|lllll|}
\hline $\begin{array}{l}\text { Olerud } \\
\text { Molander } \\
\text { score }\end{array}$ & $\begin{array}{l}\text { Group A } \\
\text { No. of } \\
\text { Patients }\end{array}$ & $\%$ & $\begin{array}{l}\text { Group B } \\
\text { No. of } \\
\text { Patients }\end{array}$ & $\%$ \\
\hline $\begin{array}{l}\text { 91-100 } \\
\text { (excellent) }\end{array}$ & 10 & 40 & 12 & 48 \\
\hline $\begin{array}{l}\text { 61-90 } \\
\text { (good) }\end{array}$ & 15 & 60 & 13 & 52 \\
\hline $\begin{array}{l}\text { 31-60 } \\
\text { (fair) }\end{array}$ & 0 & - & 0 & - \\
\hline $\begin{array}{l}\text { Mean } \\
\text { score }\end{array}$ & & 89.4 & & 90.6 \\
\hline
\end{tabular}

Most of cases of the study maintained initial reduction and showed minimal angulation in any plane (less than 5 degree). Loss of reduction was more in group B i.e. 16\% compared to $4 \%$ in group A.

Cases of study did not collapse further maintaining the length of leg bones. More than $80 \%$ cases in both groups show shortening less than $5 \mathrm{~mm}$ at final follow up.

\section{DISCUSSION}

Extra-articular distal third tibia fracture poses significant challenge to orthopedic surgeon because of paucity of soft tissue coverage, peculiar anatomy of distal tibia, significant bony comminution itself. The goal of operative treatment is to restore the anatomical alignment of distal tibia providing a sufficient stability to allow the early mobilization and minimizing the soft tissue and bony devascularization with the hope of decreasing the complications. ${ }^{2}$ For many years, IMIL nailing has been used for management of these fractures because of minimally invasive, less bleeding during surgery, early weight bearing, decreased infection rate, decreased periosteal stripping and faster healing of the fracture. Since distal tibia has wide circular intramedullary cavity with thin cortex as compared to triangular narrow cavity with thick cortex in diaphysis, intramedullary nail which is designed for interference fit in diaphysis cannot provide sufficient stability in distal region. ${ }^{9}$ With development of MIPPO technique that provides the axial and angular stability at screw plate interface rather than plate bone interface and assumed to preserve the periosteal blood supply around the fracture has challenged the IMIL nailing. ${ }^{2,10}$ Therefore it seems logical to perform the comparative study between these two techniques.

\section{Incidence of soft tissue complications}

Hazarika et al39 reported two cases of post-operative distal wound breakdown and both had a delayed presentation despite close and regular follow-up. There is no plausible explanation for this complication other than possible plate prominence in the distal region of the tibia. Metalwork problems with the $4.5 \mathrm{~mm}$ DCP used in the same manner have been attributed to the bulkiness of the implant and an incidence of post-operative metalwork discomfort along the medial aspect of the tibia, especially over the medial malleolus has been reported. Concerns have been raised regarding the development of pressure sores over the distal end of the plate, especially when under a plaster or fracture boot. However, those two cases did not have any form of external splintage at the time of wound breakdown and were also both fully weight bearing.

Plate prominence under the skin of the medial ankle and distal tibia may well be a factor in the delayed wound complications that they reported. There were no cases of delayed wound breakdown, soft tissue compromise or wound infection in our study. We suggest appropriate delay of surgery to allow soft tissue to heal and swelling to regress and Meticulous surgical technique can overcome post operative soft tissue complications to a great extent.

Francois et al concluded that their study supports the few other published studies concerning percutaneous plating of the tibia and these should inspire more trauma surgeons treating distal tibia fractures to use minimally invasive techniques, in an effort to decrease morbidity and associated complications, especially of the soft tissues. ${ }^{35}$ Minimally invasive plate osteosynthesis of the distal tibia offers several theoretical advantages compared to classic open reduction and internal fixation. A mechanically stable fracture-bridging osteosynthesis can be obtained without significant dissection and surgical trauma to the bone and surrounding soft tissues. In this retrospective study they looked at the results and complications in ten consecutive patients treated with percutaneous plating for fractures of the distal tibia and plafond with a minimum follow-up period of one year. No significant soft tissue problems occurred. The need for bone grafting should be carefully evaluated in every case as they encountered two delayed unions. All fractures healed within one year; there was no fracture malunion. The use of indirect reduction techniques and small incisions to insert hardware is technically more demanding and requires strict radioscopic control throughout the procedure, but it considerably decreases surgical trauma to the soft tissues. 
The conservative management of distal tibial fractures is known to lead to unacceptable deformity, with shortening or rotational malunion in up to $31 \%$ and ankle and subtalar stiffness (Digby, Holloway and Webb 1982; Haines et al 1984). Open reduction and plate fixation is associated with a high incidence of soft-tissue problems (Bourne 1989). Article by sarmiento (2004) says complications resulting from surgical treatment usually are more serious and difficult to overcome, infection, compartment syndrome, cortical necrosis, and breakage of the metallic implants often require repeated surgeries.

However with newer intramedullary nailing with almost no soft tissue handling these problems are overcome.

In our study none of the patient treated with IM nailing has soft tissue complication of skin necrosis compared to 4 patients out of 25 patients treated platting has skin necrosis 2 of which treated with conventional technique and two with MIPPO. However two patients treated with IM nailing complained of anterior knee pain.

\section{Shortening and malunion}

From total of 50 patients, 25 patients treated with metaphyseal plating and 25 patients treated with IM nailing none showed significant shortening, all cases had less than $10 \mathrm{~mm}$ shortening. (Significant Shortening was defined as a left/right difference in the length of the tibia of $>1 \mathrm{~cm}$ ). The average value was less than $5 \mathrm{~mm}$. Shortening is slightly higher in group treated with IM nailing but that is too not of much significance.

In our series four patients treated with IM nailing of the patient from study group had angulation greater than $5^{\circ}$ in any plane compare to only 1 patient treated with platting group but less than $10^{\circ}$. Study by Hazarika does not report incidence of shortening and malunion. Kasper et al also showed similar results but Vallier et al showed slightly higher results. $^{3}$

For alignment measurement anteroposterior and lateral radiographs were made from both legs. All radiographs were assessed digitally. The length of the tibia was defined as the distance between the anterior intercondylar area and the inferior articular surface of the tibia. Shortening was defined as a left/right difference in the length of the tibia of $>1 \mathrm{~cm}$.

Malalignment was defined as $>5^{\circ}$ ante-/recurvation, $>5^{\circ}$ varus/valgus deformity or $>15^{\circ}$ rotation difference. First, the angle between the distal part and the proximal part of the contralateral tibia was determined by measuring the angle between the line through the centre of the tibial plateau down the middle of the proximal shaft, and the line from the centre of the ankle up the middle of the distal shaft. Thereafter, the angle between the distal part and the proximal part of the consolidated tibia was measured. This was done in two directions, on anteroposterior and lateral radiographs. The difference between these angles is measured. Malalignment can lead to complaints from the patient with regard to walking, practicing sports and so forth.

Puno et al in 1991 evaluated 27 patients with 28 tibial fractures at an average of 8.2 years (range 6.0-12.3 years). They found a correlation between joint malalignment and clinical outcome for fractures of the tibia. Analysis showed that a greater degree of ankle malalignment produces poorer clinical results. They concluded that there is merit in reducing tibial fractures as close to anatomical configuration as possible to lessen the chance of early degenerative arthritis. ${ }^{20}$

In a study by Schoot et al, 88 patients who had sustained a tibial fracture were evaluated clinically and radiographically between 13 and 17 years after the injury. ${ }^{21}$ Radiographic evidence of osteoarthritis was more common on the side of the fracture than on the uninjured site. Patients with angular malunion of $>5^{\circ}$ were significantly more likely to have radiographic osteoarthritis of the knee or ankle.

There is still controversy about the acceptable angulation and shortening around the distal juxta-articular area of leg bones. According to Sarmiento et al. shortening up to 15 $\mathrm{mm}$ is less likely to produce limp.

\section{Union}

Borg et al described healing times of less than 6 months as normal, between 6 and 9 months as delayed and over 9 months as a fracture non-union. ${ }^{33}$ Within their series of 20 patients, all with extraarticular closed distal tibia fractures, they reported two delayed unions and two non-unions. In our study all patients achieved union. And hence there were no secondary procedures done. Union was slightly earlier in IM nailing group compare to platting group. Average time for union with IM nailing is 25.6 weeks compare to 27.1 weeks in platting group. Tyllianakis et al reviewed 73 patients with distal tibial fractures treated with reamed nailing and reported union in $96 \%$ of the patients.

In Kasper et al study, the mean time to radiographic union was 19 weeks (range 14-32 weeks) for the ORIF group versus 21 weeks (range 13-28 weeks) for the IM nailing group.

Again in study by Yong et al show similar result to our study. In their study the mean time for union for fracture in nailing group is 21.3 week and is slightly short compare to platting group i.e. 23.1 weeks.

\section{Olerud Molander ankle score}

OMA score for each patient was calculated at final follow up. Our results showed $40 \%$ patients of platting group and $48 \%$ patients of IM nailing group had excellent results. 
Mean OMA score in platting group is 89.4 and in IM nailing group is 90.6 .

Another study of Gun et al say in their study that OMA scores in the two groups were comparable. Group I (treated with intramedullary nail), group 2 (treated with open reduction and plate fixation) obtained $88.5 \%$ and $88.2 \%$ respectively. Satisfactory or excellent results were obtained in $86.3 \%$ of patients in Tyllianakis et al study in 2000. Also similar results were reproduced in Robinson et al with nailing where functional outcome was excellent to satisfactory in $91.6 \%$ patients. We were able to achieve better functional results with close intramedullary nailing.

The sample size of our study was small due to some unavoidable and unfortunate reasons. Some of them to be mentioned are limited availability of image intensifier, poor socio-economic status of our patients, limited availability and affordability of good quality standard implants. We accept the biggest shortcoming of our study was small sample size. We hope in future more and more patients will be able to gain shining effects of metaphyseal locking plate as a proven modality of treatment for distal periarticular leg bone fractures.

\section{CONCLUSION}

We conclude that both closed intramedullary nailing and a locked compression plate can be used safely to treat Orthopaedic Trauma Association type-43A distal metaphyseal fractures of the tibia. Our results have shown that locked intramedullary nails have an advantage in the duration of operation, restoration of motion, and reduced wound problems, and anatomic plate and screws can restore alignment better than intramedullary nails. Due to the small numbers of patients involved in our study, we cannot draw any definitive conclusions from our preliminary results but view them as a valuable basis for future studies.

Funding: No funding sources

Conflict of interest: None declared

Ethical approval: The study was approved by the institutional ethics committee

\section{REFERENCES}

1. Tornetta P, Court-Brown C, Heckman JD, McKee M, McQueen MM, Ricci W et al. Rockwood, Green, and Wilkins fractures in adults and children: Eighth edition. 2014;4026.

2. Court-Brown CM, Birnie MCJ. The epidemiology of tibia fractures, Jbone Joint Surg. 1995;77B:417-21.

3. Vallier HA, Le TT, Bedi A. Radiographic and clinicalcomparisons of distal tibia shaft fractures: Platingversus intramedullary nailing. J Orthop Trauma. 2008;22:15-22.

4. Zelle BA, Bhandari M, Espiritu M. Treatment of distaltibia fractures without articular involvement: a systematic reviewof 1125 fractures. J Orthop Trauma 2006;20(1):96-9.

5. Bedi A, Le TT, Karunakar MA. Surgical treatment of nonarticulardistal tibia fractures. J Am Acad Orthop Surg. 2006;14(7):256-9.

6. Anglen JO. Early outcome of hybrid external fixation for fracture of the distal tibia. J orthop Trauma. 1999;13:92-97.

7. Watson JT, Moed BR, Karges DE, Cramer KE. Pilon fractures. Treatment protocol based on severity of soft tissueinjury. Clin orthop Relat Res. 2000;375:78-90.

8. Gueorguiev B, Ockert B, Schwieger K, Wahnert D, Lawson-Smith M, Windolf M, et al. Angular stability potentiallypermits fewer locking screws compared with conventional lockingin intramedullary nailed distal tibia fractures: a biomechanicalstudy. J Orthop Trauma. 2011;25(6):29-35.

9. Mosseiff R, Safran O, Segal D. The unreamedtibial nail in the treatment of distal metaphyseal fractures. Injury. 1999;30:21-25.

10. Jenssen KW, Biert J, Van Kampen A. Treatment ofdistal tibia fractures: Plate versus nail: A retrospectiveoutcome analysis of matched pairs of patients. Int Orthop. 2007;31:33-9.

11. Tyllianakis $\mathrm{M}$, Megas $\mathrm{P}$, Giannikas D. interlockingintramedullary nailing in distal tibia fractures. Orthopedics. 2000;23:85-90.

12. Mosseiff R, Safran O, Segal D. The undreamed tibial nail in the treatment of distal metaphyseal fractures. Injury. 1999;30:115-20.

13. Chen AL, Tejwani NC, Joseph TN, Kummer FJ, Koval KJ. The effect of distal screw orientation on the intrinsic stability of a tibial intramedullary nail. Bull Hosp Jt Dis. 2001;117-21.

14. Freedman EL, Johnson EE. Radiographic analysis of tibial fracture malalignment following intramedullary nailing. Clin Orthop Relat Res. 1995;315:96-110.

15. Robinson CM, McLauchlan GJ, McLean IP, CourtBrown CM. Distal metaphyseal fractures of the tibia with minimal involvement of the ankle. Classification and treatment by locked intramedullary nailing. J Bone Joint Surg Br. 1995;77:85-8.

16. Tanna DD. Interlocking nailing. 2nded. New Delhi: Jaypee Publishers. 2004;105-25.

17. Krettek C, Miclau T, Schandelmaier P. The mechanical effectof blocking screws ("Poller screws") in stabilizing tibia fractures withshort proximal or distal fragments after insertion of small diameterintramedullary nails. J Orthop Trauma. 1999;5:56-8.

18. MIPPO. An update current orthopaedics. 2008;22(3):202-7.

19. Milner SA. A more accurate method of measurement of angulation after fractures of the tibia. J Bone Joint Surg Br. 1997;79:53-9. 
20. Puno RM, Vaughan JJ, Stetten ML. Long-term effects of tibial angular malunion on the knee and ankle joints. J Orthop Trauma. 1991;3:5-8.

21. Ian P, Awen I. Indirect reduction using a simple quadrilateral frame in the in the application of distal tibial LCP-technical tips. Injury. 2005;36(9):113842.

22. Newman SD, Mauffrey CP, Krikler S. Distal metadiaphyseal tibial fractures. Injury. 2010;41(7):15-20.

23. Ronga M, Shanmugam C, Longo UG. Minimally invasive osteosynthesis of distal tibial fractures using lockingplates. Orthop Clin North Am. 2009;40(4):230-5.

24. Dogra AS, Ruiz AL, Thompson NS. Diametaphysealdistal tibial fractures: treatment with a shortened intramedullarynail: a review of 15 cases. Injury. 2000;31:159-65.

25. Gorczyca JT, McKale J, Pugh K. Modified tibial nails for treating distal tibia fractures. J Orthop Trauma. 2002;16:18-22.

26. Olerud C, Molander H. A scoring scale for symptom evaluation after ankle fracture. Arch Orthop Trauma Surg. 1984;103:52-60.

27. Gustilo RB, Anderson JT. The prevention of infection intreatment of 1000 and 25 open fractures of long bones-retrospectiveand prospective analysis. J Bone Joint Surg Am. 1976;58(4):205-10.

28. Kuhn S, Hansen M, Rommers PM. Extending the indicationof intra medullary nailing of tibial fractures. Eur J Trauma Emerg Surg. 2008;75(2):126-31.

29. Ibrahimi AE, Shimi M, Daoudi A. Intramedullarynailing in the management of distal tibial fractures. Current Orthopaedic Practice. 2009;20(3):209-20.

30. Court-Brown CM, Christie J, McQueen MM. Closed intramedullary tibial nailing. Its use in closed and type I open fractures. J Bone Joint Surg Br. 1990;72(4):78-89.

31. Bucholz RW, Heckman JD. Rockwood and Green'sfractures in adults, Sixth ed. Lippincott Williams and Wilkins. 2007;185-95.

32. Court-Brown CM, MC Birnie J. The epidemiology of tibia fractures. J Bone Joint Surg. 1995;77B.

33. Borg T, Larsson S, Lindsjo U. Percutaneous plating of distal tibia fractures: Preliminary results in 21 patients. Injury. 2004;35:200-5.

34. Muller ME, Nazarian S, Koch P. The comprehensive classification of fractures of long bones. Berlin:Springer - Verlag. 1990;75-8.

35. Francois J, Vandeputte G, Veheyden F. Percutaneousplate fixation of fractures of the distal tibia. ActaOrthop Belg. 2004;70:105-8.

36. Helfet DL, Shonnard PY, Levine D. Minimallyinvasive plate osteosynthesis of distal fractures of the tibia. Injury. 1997;28:A42-7.
37. Bombaci H, Guneri B, Gorgec M, Kafadar A. A comparison between locked intramedullary nailing andplate and screw fixation in the treatment of tibial diaphysealfractures. Acta Orthop Traumatol Turc. 2004;38:51-3.

38. Borrelli J, Jr, Prickett W, Song E, Becker D, Ricci W. Extraosseous blood supply of the tibia and the effects of different plating techniques: a human cadaveric study. J Orthop Trauma. 2002;16(10):3-5.

39. Hazarika S, Chakravarthy J, Cooper J. Minimally invasive locking plate osteosynthesis for fractures of the distal tibia-results in 20 patients. Injury. 2006;37(9):156-66.

40. Oh CW, Kyung HS, Park IH, Kim PT, Ihn JC. Distal tibial metaphyseal fractures treated by percutaneous plate osteosynthesis. Clin Orthop Relat Res. 2003;18:15-22.

41. Redfern DJ, Syed SU, Davies SJ. Fractures of the distal tibia: minimally invasive plate osteosynthesis. Injury. 2004;35(6):185-91.

42. Borg T, Larsson, Lindsjo U. Percutaneous plating of distal tibial fractures. Preliminary results in 21 patients. Injury. 2004;35:56-9.

43. Collinge C, Sanders R, DiPasquale T. Treatment of complex tibial periarticular fractures using percutaneous techniques. Clin Orthop. 2000;375:8996.

44. Rao H, Patil SR, Sharma LR. Clinical study of fractures in lower third tibia. Indian Journal of Orthopedics. 1999;33(4):145-9.

45. Pradyumna PP, Raiturker AA, Salunkhe. Minimally invasive plate osteoynthesis (mipo) in the treatment of multifragmentary fractures of the tibia. 2012;3(4):14-9.

46. Sarmiento A, Latta LL. 450 closed fractures of the distal third of the tibia treated with a functional brace. Clin Orthop Relat Res. 2004;428:261-71.

47. Tscherne H, Gotzen L. Fractures with soft tissue injuries Berlin: Springer-Verlag. 1984;2(1):12-4.

48. Court-Brown CM, Gustilo T, Shaw AD. Knee pain after intramedullarytibial nailing: its incidence, etiology, and outcome. J Ortho Trauma. 1997;11:2533.

49. Robinson CM, McLauchlan GJ, McLean IP. Distal metaphyseal fractures of the tibia with minimal involvement of the ankle. Classification and treatment by locked intramedullary nailing. J Bone Joint Surg Br. 1995;77:189-200.

50. Kumar A, Charlebois SJ, Cain EL Effect of fibular plate fixation on rotational stability of simulated distal tibia fractures treated with intramedullary nailing. J Bone Joint Surg Am. 2003;85:203-8.

Cite this article as: Kumar A, Juneja J, Choubsia R, Jeenjwadia N, Mehra AK, Rameshsen. Comparative study between intramedullary interlocking nailing and minimally invasive percutaneous plate osteosynthesis for distal tibia extra-articular fractures. Int J Res Orthop 2021;7:1177-84. 